\title{
Availability and accessibility of information regarding the protection of athletes' health and promotion of sport for health to the general population on the websites of French Olympic Sports Federations
}

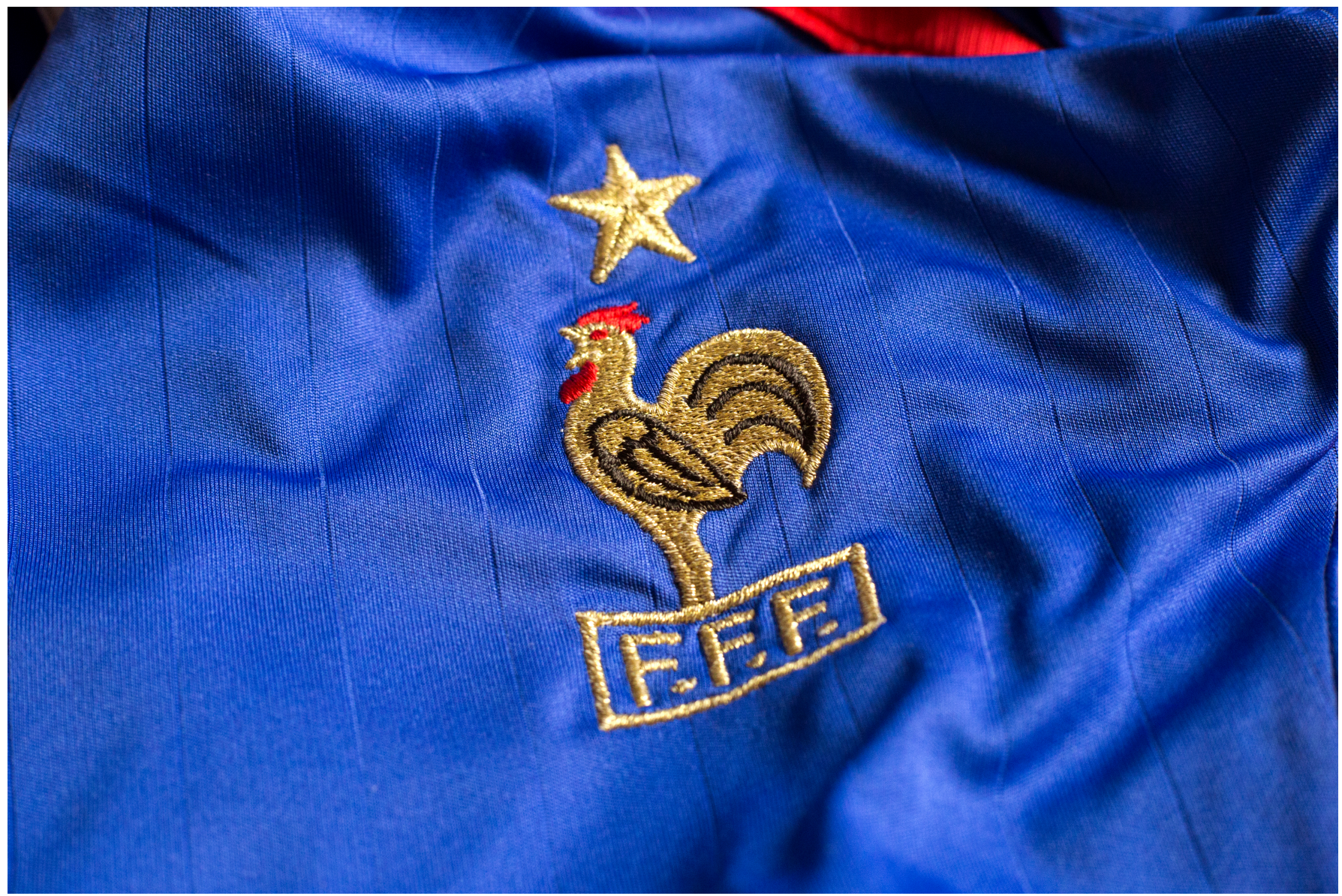

Merley Marie-Emilie ${ }^{1}$, Gremeaux Vincent ${ }^{2,3}$, Edouard Pascal ${ }^{1,2,4}$

${ }^{1}$ Department of Clinical and Exercise Physiology, Sports Medicine Unit, University Hospital of SaintEtienne, Faculty of Medicine, Saint-Etienne, France

${ }^{2}$ Swiss Olympic Medical Centre, Centre de médecine du sport, Division de médecine physique et 
réadaptation, Centre Hospitalier Universitaire Vaudois, Lausanne, Switzerland

${ }^{3}$ Institute of Sport Sciences, University of Lausanne, Lausanne, Switzerland

4 Interuniversity Laboratory of Human Movement Biology (LIBM EA 7424), University of Lyon, University Jean Monnet, F-42023 Saint Etienne, France

\section{Abstract}

Background: Diffusion of information regarding 'protecting athletes' health' and the 'promotion of sport for health of the general population' is a mission of National Sports Federations. Internet is a commonly used source of health-related information. The Olympic Games (OG) are an opportunity for a nation to promote the health benefits of sport.

Objective: To analyse the availability and accessibility of health-related information on French National Olympic Sports Federation (FOFs) websites just after the bid in 2015 for the 2024 OG and six months after official assignment (2018) of the games to Paris.

Methods: This descriptive study analysed the availability and accessibility of information regarding athletes' health protection and the promotion of sport for health for all, on FOF websites, using a list of 12 different topics and two check lists (Google score (GS) and Website score (WS)) in September 2015 and March 2018.

Results: The websites of 31 and 36 FOFs were analysed in 2015 and 2018, respectively. In 2015, 32.3\% of FOFs reached a GS $\geq 75 \%$ : this was 50\% in 2018. From 2015 to 2018, there was a significant increase in the availability of information on FOF website based on GS (mean increase of $41.2 \%$; $p=0.004$ ) and a tendency to increase for availability and accessibility based on WS (mean increase of $21.4 \% ; p=0.07$ ).

Conclusions: The FOFs are engaged in diffusing health-related information via their websites, although the availability and accessibility of this information varies according to FOFs and topics.

\section{Résumé}

Contexte: La diffusion d'informations sur «la protection de la santé des athlètes» et la "promotion du sport pour la santé de la population » est une mission des fédérations sportives nationales. Internet est une source d'information sur la santé couramment utilisée. Les Jeux Olympiques sont une occasion pour un pays de promouvoir les bienfaits du sport sur la santé.

Objectif: Analyser la disponibilité et l'accessibilité des informations relatives à la santé sur les sites Internet des fédérations nationales françaises de sport Olympique (FFO) juste après la candidature en 2015 pour l'organisation des Jeux Olympiques en 2024 à Paris et six mois après l'attribution officielle des jeux à Paris (2018).

Méthodes: Cette étude descriptive a analysé la disponibilité et l'accessibilité des informations relatives à la protection de la santé des athlètes et à la promotion du sport pour la santé pour tous sur les sites Internet des FFO, à l'aide d'une liste de 12 différents domaines et de deux scores: score Google (SG) et score Web (SW), en septembre 2015 et mars 2018.

Résultats: Les sites Internet de 31 et 36 FFO ont été analysés en 2015 et 2018, respectivement. En 2015, $32,3 \%$ des FFO ont atteint un SG $\geq 75 \%$, et 50\% en 2018. De 2015 à 2018, le nombre d'informations disponibles sur les sites Internet des FFO a augmenté: sur le SG on notait une augmentation moyenne de 
$41,2 \% ; \mathrm{p}=0,004$, et une tendance à la hausse pour la disponibilité et l'accessibilité avec le SW (augmentation moyenne de $21,4 \% ; p=0,07$ ).

Conclusions: Les FFO sont engagées dans la diffusion d'informations relatives à la santé via leurs sites Internet, bien que la disponibilité et l'accessibilité de ces informations varient selon les FFO et les domaines.

\section{What are the new findings?}

- Availability of health-related information varied between FOFs without any correlation with the size of the FOF (number of members).

- The accessibility of the health-related information varied according to topics. How might this impact on clinical practice in the near future?

These results should help FOFs in orienting their efforts to improve the availability and accessibility of information for the health protection of athletes and health promotion through sport on their websites. FOFs should be fully exploiting the potential of this great communication tool and using it to communicate with and inform athletes, coaches and health-care professionals.

\section{Introduction}

The protection of athletes' health and the promotion of health and physical activity for the whole population are two of the clearly stated aims of the International Olympic Committee (IOC) and International Sports Federations (IFs), and consequently of all National Olympic Committees (NOCs) and National Sports Federations (NFs) [1-4]. Diffusing information on these topics is also an important part of these governing sporting bodies' mission, as stated in the Olympic Movement Medical Code (OMMC) [2], and in stage 6 of the Translating Research into Injury Prevention Practice (TRIPP) framework [5]. This type of information would be of interest to: i) health-care professionals helping them improve athletes' medical care and education, and encourage sport promotion for health, ii) athletes, coaches, and/or athletes' caregivers to improve health, training practice and lifestyle, and iii) the general population to encourage sporting practice.

We felt it logical that NFs would have the major role in this, because: i) athletes, coaches and health professionals may be members of these NFs; ii) clubs affiliated to these NFs are known to the general and sporting population in the vicinity; iii) NFs are better known than IFs by athletes and the general population; iv) NFs can disseminate information provided by the IOC, NOCs and IFs, in the language of their members; v) health professionals, coaches and athletes can contact NFs with health or sport-related questions; vi) NFs have medical commissions; vii) NFs are trusted; and viii) NFs are more sport-specific than NOCs. Since this information needs to be easy to find, and the Internet regularly used as a source of health information [6-8], we felt that looking at the information available on NFs websites would be an easy way to analyse health-related information dissemination.

The Olympic Games (OG), as the most famous sporting event of all time, is an opportunity for a nation to develop sport awareness, highlighting the sporting performance and excellent health that wins Olympic medals [9,10], whilst promoting sport and exercise for all as a public health goal [11]. In the preparation of the 'Paris 2024' OG (http://www.paris2024.org/fr), such strategies and messages should be included by the 
French Olympic Sports Federations (FOFs).

In this context, we aimed 1) to analyse exactly what health-related information was available on the websites of FOFs and measure how easy it was to find this information, and 2) to analyse the evolution in the available information between the time of making the bid and six months after Paris was officially awarded the 2024 OG.

\section{Methods}

\subsection{Procedure}

This descriptive study analysed the availability and accessibility of health-related information on the websites of FOFs, using a list of different topics and two check lists (Google score and Website score), in September 2015 (three months after Paris made its bid for the 2024 OG) and March 2018 (six months after Paris was awarded the 2024 OG).

\subsection{The French Olympic Sports Federations}

We chose to analyse only information from FOFs because: i) they are the NFs of sports included in the games so part of 'Paris 2024'; ii) they represent IFs at a national level; iii) they are responsible for protecting the health of their athletes and promoting physical activity via their sport to improve the health of the general population [1-4]; iv) they are most often structured as associations or federations; v) they usually have media and financial support; and vi) they are the 'showcase' of their sport with the general public.

\subsection{List of different topics}

We created a list of different topics, designed to cover that developed by Mountjoy and Junge [3], the main areas of Sports Medicine [12], the principal topics discussed by medical commissions of IFs and NFs, the questions heard in clinical practice from athletes or patients who want to start a physical activity and an initial screening of FOF websites, based on the authors' experience of general practice and sports medicine and with the help of the head of a local branch of a French sporting federation. The 12 topics were listed in Table 2 .

\subsection{Data collection using scores}

In order to objectively analyse the information disseminated by the FOFs, we used two scores: the Google score (GS) and the Website score (WS). Each FOF and each topic were scored first with the GS and then with the WS. A single investigator/author (MEM) carried out all the searches during private browsing sessions so that her personal data would not influence the results.

\subsubsection{Google score}

We chose the Google search engine as it is the most used and known to be comprehensive, especially for health information, and as it includes documents in .pdf, .doc and .ppt formats [13,14]. We searched using a combination of the complete name of each FOF and each topic e.g. 'french federation of athletics recommendations on injury prevention'. All words were in French, without quotation marks, without capital letters and without the Boolean search operator 'AND'. If a link to the corresponding webpage of 
the FOF for the topic under consideration appeared within the first two pages of results, 1 point was awarded. Reformulation of the topic was used if the initial topic term was 'not found'. For each topic, the GS could be either 1 or 0 depending on whether the topic appeared within the first two pages of results, giving a maximum possible for each FOF of 12 points. GS is reported as a percentage of the maximal score.

\subsubsection{Website score}

Starting from the home page of each FOF website, a search was performed to find information related to each topic in order to evaluate the availability and accessibility of the information and scored as follows: 3 points if the information was present on the home page; 2 points if it was findable using the site map; 1 point if it was difficult to find; 0 points if nothing was found even after using the website's internal search engine. We aimed to reproduce how an athlete or health professional would actually search the Internet, including a time limitation. The maximal WS was thus 36 for each FOF; 0-3 points for each of 12 topics. WS is reported as a percentage of the maximal score.

\subsection{Data analyses}

First, descriptive analyses were performed regarding the availability and accessibility of information using GS and WS results as frequency. A topic was considered as available if either the GS or WS was at least 1, as many people would go directly to the website of their chosen sport and bypass the search engine. Comparisons were then made between the values obtained in 2015 vs. 2018, for each FOF and each topic, using a Student t-test. Finally, comparisons were made between team vs. individual sports and between summer vs. winter sports federations using a Student t-test. Correlations between each FOF's membership and GS and WS were analysed using the Pearson correlation coefficient. Significance was accepted at $\mathrm{p}<0.05$. Data were processed using Excel software.

\section{Results}

For the FOFs ( $n=31$ in 2015, and $n=36$ in 2018), the GS and WS varied from $16.7 \%$ to $100 \%$ (Table 1). In 2015, $32.3 \%$ of FOFs had a GS $\leq 75 \%$; this rose to 50\% in 2018 (Table 1). From 2015 to 2018, there was a significant increase in the availability of information on the FOF websites based on GS (mean increase of 41.2\%; $\mathrm{p}=0.004$ ) and a tendency to increased availability and accessibility based on WS (mean increase of $21.4 \%$; $\mathrm{p}=0.07)$. $58.1 \%$ of FOFs increased their GS and $64.5 \%$ their WS, although $25.8 \%$ and $22.6 \%$ decreased their GS and WS, respectively.

Depending on the topic, there was no significant increase over time for the availability of information (mean increase of 7.5\%; $\mathrm{p}=0.2$ ) (Table 2 and Figure 1 ). 
A Availability of topics on FOFs websites in 2015

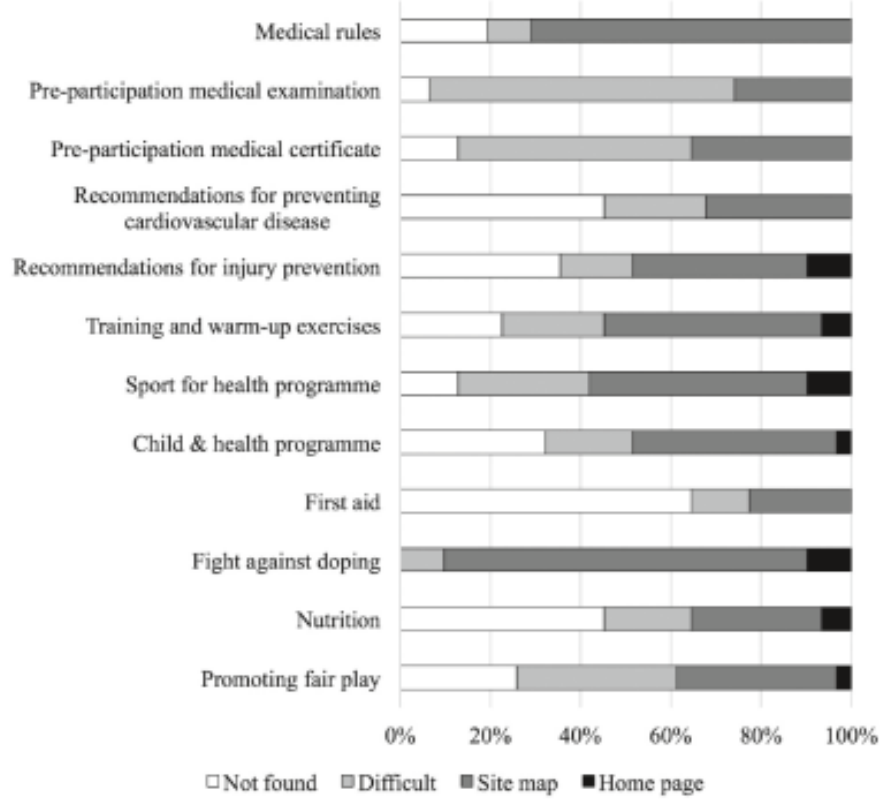

B Availability of topics on FOFs websites in 2018

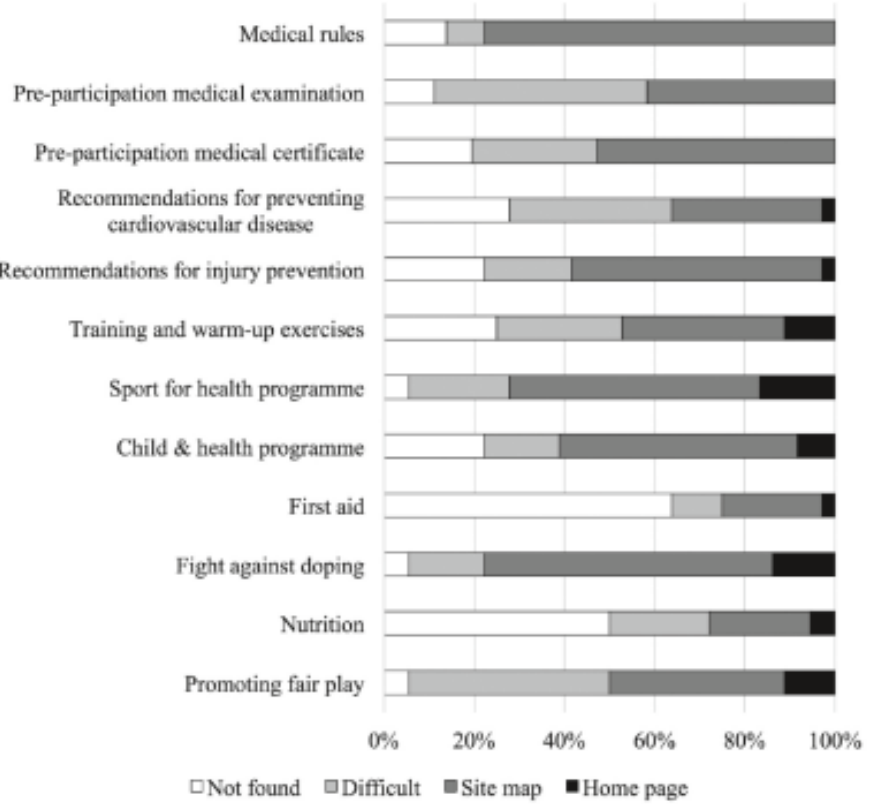

Figure 1: Availability of information based on the Website Score according to the topics for all analysed French Olympic Sports Federations (FOFs) in 2015 (A) and 2018 (B). 


\begin{tabular}{|c|c|c|c|c|c|c|c|c|c|c|c|c|c|}
\hline \multirow{3}{*}{$\begin{array}{l}\text { Sports } \\
\text { Athletics }\end{array}$} & \multirow{3}{*}{$\begin{array}{l}\text { NFs } \\
\text { FFA }\end{array}$} & \multirow{3}{*}{$\begin{array}{l}\begin{array}{l}\text { Year of } \\
\text { NF } \\
\text { foun- } \\
\text { dation }\end{array} \\
1920\end{array}$} & \multirow{2}{*}{\multicolumn{2}{|c|}{$\begin{array}{l}\text { Number of } \\
\text { members } \\
\text { (in thousands] } \\
\text { for given year }\end{array}$}} & \multirow{3}{*}{$\begin{array}{l}\text { IFs } \\
\text { IAAF }\end{array}$} & \multirow{3}{*}{$\begin{array}{l}\begin{array}{l}\text { Sum- } \\
\text { mer/ } \\
\text { Winter }\end{array} \\
\text { S }\end{array}$} & \multirow{3}{*}{$\begin{array}{l}\text { Individ- } \\
\text { ual/ } \\
\text { Team } \\
\text { sport }\end{array}$} & \multicolumn{3}{|c|}{ Google score } & \multicolumn{3}{|c|}{ Website score } \\
\hline & & & & & & & & \multirow{2}{*}{\begin{tabular}{|l|}
2015 \\
83.3 \\
\end{tabular}} & \multirow{2}{*}{\begin{tabular}{|l|}
2018 \\
75.0 \\
\end{tabular}} & \multirow{2}{*}{\begin{tabular}{|l|}
$\begin{array}{l}\% \text { of } \\
\text { change }\end{array}$ \\
-10.0
\end{tabular}} & \multirow{2}{*}{\begin{tabular}{|l|}
2015 \\
58.3 \\
\end{tabular}} & \multirow{2}{*}{$\begin{array}{l}2018 \\
63.9\end{array}$} & \multirow{2}{*}{$\begin{array}{l}\begin{array}{l}\% \text { of } \\
\text { change }\end{array} \\
9.5\end{array}$} \\
\hline & & & 314.7 & 2018 & & & & & & & & & \\
\hline Rowing & $\begin{array}{l}\text { FFAvi- } \\
\text { ron }\end{array}$ & 1890 & 47.0 & 2017 & FISA & $\mathrm{S}$ & I & 75.0 & 75.0 & 0.0 & 55.6 & 44.4 & -20.0 \\
\hline $\begin{array}{l}\text { Bad- } \\
\text { minton }\end{array}$ & FFBaD & 1934 & 188.2 & 2018 & BWF & S & I & 41.7 & 75.0 & 80.0 & 27.8 & 58.3 & 110.0 \\
\hline $\begin{array}{l}\text { Baseball } \\
\text { Softball }\end{array}$ & FFBS & 1924 & 13.1 & 2017 & WBSC & $\mathrm{S}$ & $\mathrm{T}$ & - & 33.3 & NA & - & 19.4 & NA \\
\hline Basketball & FFBB & 1932 & 681.6 & 2018 & FIBA & S & $\mathrm{T}$ & 41.7 & 58.3 & 40.0 & 30.6 & 44.4 & 45.5 \\
\hline Boxing & FFB & 1903 & 60.0 & 2018 & AIBA & $\mathrm{S}$ & 1 & 50.0 & 66.7 & 33.3 & 30.6 & 38.9 & 27.3 \\
\hline Canoe & FFCK & 1931 & 365.0 & 2014 & ICF & $\mathrm{S}$ & 1 & 50.0 & 50.0 & 0.0 & 30.6 & 33.3 & 9.1 \\
\hline Cycling & FFC & 1881 & 119.3 & 2018 & $\mathrm{UCl}$ & $\mathrm{S}$ & 1 & 41.7 & 58.3 & 40.0 & 25.0 & 33.3 & 33.3 \\
\hline $\begin{array}{l}\text { Equestri- } \\
\text { an }\end{array}$ & FFE & 1921 & 650.0 & 2017 & FEI & $\mathrm{S}$ & I & 41.7 & 66.7 & 60.0 & 27.8 & 58.3 & 110.0 \\
\hline $\begin{array}{l}\text { Sport } \\
\text { Climbing }\end{array}$ & FFME & 1945 & 101.4 & 2017 & $\begin{array}{l}\text { IFSC/ } \\
\text { ISMF }\end{array}$ & $\mathrm{S}$ & I & - & 75.0 & NA & - & 69.4 & NA \\
\hline Fencing & $\begin{array}{l}\text { FFE- } \\
\text { scrime }\end{array}$ & $\begin{array}{l}1882- \\
1906\end{array}$ & 56.8 & 2018 & FIE & S & I & 75.0 & 75.0 & 0.0 & 47.2 & 47.2 & 0.0 \\
\hline Football & FFF & $\begin{array}{l}1907- \\
1919\end{array}$ & $2,160.8$ & 2017 & FIFA & $\mathrm{S}$ & $\mathrm{T}$ & 58.3 & 66.7 & 14.3 & 50.0 & 52.8 & 5.6 \\
\hline Golf & FFGolf & 1912 & 410.3 & 2017 & IGF & $\mathrm{S}$ & 1 & 75.0 & 83.3 & 11.1 & 63.9 & 63.9 & 0.0 \\
\hline $\begin{array}{l}\text { Gymnas- } \\
\text { tics }\end{array}$ & FFGym & $\begin{array}{l}1873- \\
1912- \\
1942\end{array}$ & 300.0 & 2017 & FIG & S & I & 83.3 & 41.7 & -50.0 & 47.2 & 11.1 & -76.5 \\
\hline $\begin{array}{l}\text { Weight- } \\
\text { lifting }\end{array}$ & $\begin{array}{l}\text { FFHM- } \\
\text { FAC }\end{array}$ & $\begin{array}{l}1914- \\
2000- \\
2015\end{array}$ & 53.3 & 2014 & IWF & S & I & 33.3 & 83.3 & 150.0 & 47.2 & 52.8 & 11.8 \\
\hline Handball & $\begin{array}{l}\text { FF- } \\
\text { Hand- } \\
\text { ball }\end{array}$ & $\begin{array}{l}1935- \\
1941\end{array}$ & 664.8 & 2017 & IHF & $\mathrm{S}$ & $\mathrm{T}$ & 83.3 & 100.0 & 20.0 & 55.6 & 61.1 & 10.0 \\
\hline Hockey & $\begin{array}{l}\text { FF- } \\
\text { Hockey }\end{array}$ & $\begin{array}{l}1899- \\
1920\end{array}$ & 17.1 & 2018 & $\mathrm{FIH}$ & $\mathrm{S}$ & $\mathrm{T}$ & 58.3 & 66.7 & 14.3 & 30.6 & 33.3 & 9.1 \\
\hline Ice Hockey & FFHG & 2006 & 21.5 & 2017 & IIHF & W & $\mathrm{T}$ & 50.0 & 50.0 & 0.0 & 44.4 & 41.7 & -6.2 \\
\hline Judo & FFJudo & 1946 & 570.0 & 2018 & IJF & $\mathrm{S}$ & 1 & 66.7 & 75.0 & 12.5 & 58.3 & 63.9 & 9.5 \\
\hline Karaté & FFK & 1975 & 247.6 & 2016 & WKF & S & I & - & 75.0 & NA & - & 44.4 & NA \\
\hline Wrestling & $\mathrm{FFL}$ & 1913 & 20.4 & 2018 & UWW & $\mathrm{S}$ & I & 25.0 & 25.0 & 0.0 & 16.7 & 19.4 & 16.7 \\
\hline Aquatics & FFN & $\begin{array}{l}1921- \\
1938\end{array}$ & 316.9 & 2017 & FINA & S & $\mathrm{I} / \mathrm{T}$ & 83.3 & 83.3 & 0.0 & 61.1 & 66.7 & 9.1 \\
\hline $\begin{array}{l}\text { Modern } \\
\text { Pentath- } \\
\text { lon }\end{array}$ & $\begin{array}{l}\text { FFPen- } \\
\text { tathlon }\end{array}$ & 1912 & 1.8 & 2016 & UIPM & S & I & 66.7 & 58.3 & -12.5 & 22.2 & 19.4 & -12.5 \\
\hline Rugby & FFR & $\begin{array}{l}1907- \\
1920\end{array}$ & 438.1 & 2018 & WR & S & $\mathrm{T}$ & 83.3 & 83.3 & 0.0 & 55.6 & 61.1 & 10.0 \\
\hline $\begin{array}{l}\text { Skate- } \\
\text { board }\end{array}$ & FFRS & $\begin{array}{l}1977- \\
1997\end{array}$ & 69.2 & 2017 & WSk & $\mathrm{S}$ & 1 & - & 50.0 & NA & - & 30.6 & NA \\
\hline $\begin{array}{l}\text { Skiing, } \\
\text { Biathlon }\end{array}$ & FFS & 1924 & 106.0 & 2018 & $\begin{array}{l}\text { FIS, } \\
\text { IBU }\end{array}$ & W & 1 & 91.7 & 83.3 & -9.1 & 58.3 & 52.8 & -9.5 \\
\hline
\end{tabular}




\begin{tabular}{|c|c|c|c|c|c|c|c|c|c|c|c|c|c|}
\hline \multirow{3}{*}{$\begin{array}{l}\text { Sports } \\
\text { Ice Sports }\end{array}$} & \multirow{3}{*}{$\begin{array}{l}\text { NFs } \\
\\
\text { FFSG }\end{array}$} & \multirow{3}{*}{$\begin{array}{l}\begin{array}{l}\text { Year of } \\
\text { NF } \\
\text { foun- } \\
\text { dation }\end{array} \\
1903- \\
1941\end{array}$} & \multirow{2}{*}{\multicolumn{2}{|c|}{$\begin{array}{l}\text { Number of } \\
\text { members } \\
\text { (in thousands) } \\
\text { for given year }\end{array}$}} & \multirow{3}{*}{$\begin{array}{l}\text { IFs } \\
\\
\text { IBSF, } \\
\text { WCF, } \\
\text { ISU }\end{array}$} & \multirow{3}{*}{$\begin{array}{l}\begin{array}{l}\text { Sum- } \\
\text { mer/ } \\
\text { Winter }\end{array} \\
\text { W }\end{array}$} & \multirow{3}{*}{$\begin{array}{l}\begin{array}{l}\text { Individ- } \\
\text { ual/ } \\
\text { Team } \\
\text { sport }\end{array} \\
\text { I }\end{array}$} & \multicolumn{3}{|c|}{ Google score } & \multicolumn{3}{|c|}{ Website score } \\
\hline & & & & & & & & \multirow{2}{*}{$\begin{array}{l}2015 \\
8.3\end{array}$} & \multirow{2}{*}{\begin{tabular}{|l|}
2018 \\
58.3
\end{tabular}} & \multirow{2}{*}{$\begin{array}{l}\begin{array}{l}\% \text { of } \\
\text { change }\end{array} \\
600.0\end{array}$} & \multirow{2}{*}{\begin{tabular}{|l|}
2015 \\
13.9
\end{tabular}} & \multirow{2}{*}{\begin{tabular}{|l|}
2018 \\
13.9
\end{tabular}} & \multirow{2}{*}{\begin{tabular}{|l|}
$\begin{array}{l}\% \text { of } \\
\text { change }\end{array}$ \\
0.0
\end{tabular}} \\
\hline & & & 33.2 & 2017 & & & & & & & & & \\
\hline Surf & FFSurf & 1964 & 80.0 & 2018 & ISA & S & 1 & - & 41.7 & NA & - & 41.7 & NA \\
\hline $\begin{array}{l}\text { Taek- } \\
\text { wondo }\end{array}$ & FFTDA & $\begin{array}{l}1976- \\
1995\end{array}$ & 54.2 & 2018 & WTF & $\mathrm{S}$ & I & 58.3 & 58.3 & 0.0 & 50.0 & 41.7 & -16.7 \\
\hline Tennis & FFT & $\begin{array}{l}1920- \\
1976\end{array}$ & $1,039.3$ & 2017 & ITF & $\mathrm{S}$ & I & 91.7 & 83.3 & -9.1 & 61.1 & 55.6 & -9.1 \\
\hline $\begin{array}{l}\text { Table } \\
\text { tennis }\end{array}$ & FFTT & 1927 & 20.5 .5 & 2018 & ITTF & S & I & 41.7 & 66.7 & 60.0 & 8.3 & 30.6 & 266.7 \\
\hline Shooting & FFTir & 1965 & 223.9 & 2018 & ISSF & $S$ & I & 50.0 & 66.7 & 33.3 & 36.1 & 36.1 & 0.0 \\
\hline Archery & FFTA & $\begin{array}{l}1899- \\
1928\end{array}$ & 75.5 & 2018 & WA & $S$ & I & 66.7 & 75.0 & 12.5 & 47.2 & 63.9 & 35.3 \\
\hline Triathlon & FFTri & 1989 & 50.3 & 2018 & ITU & S & I & 41.7 & 83.3 & 100.0 & 27.8 & 44.4 & 60.0 \\
\hline Sailing & FFV & $\begin{array}{l}1946- \\
1975\end{array}$ & 116.9 & 2018 & WS & $\mathrm{S}$ & I & 58.3 & 83.3 & 42.9 & 58.3 & 63.9 & 9.5 \\
\hline Volleyball & FFVB & 1936 & 136.4 & 2018 & FIVB & $\mathrm{S}$ & $T$ & 58.3 & 83.3 & 42.9 & 33.3 & 38.9 & 16.7 \\
\hline Mean & & & 278.1 & & & & & 59.1 & 67.6 & 41.2 & 41.3 & 44.9 & 21.4 \\
\hline SD & & & 403.4 & & & & & 20.5 & 16.4 & 110.6 & 15.9 & 16.1 & 57.2 \\
\hline
\end{tabular}

Table 1: Characteristics of the French Olympic Sports Federations and results of the Google score and Website score in 2015 and 2018 (in percentages), with the percentage of change from 2015 to 2018.

W, winter; S, summer; I, individual sport; T, team sport (defined by the International Team Sport Federation Committee as two opposing groups of players on the field of play at the same time[3,4]); NA, not applicable.

Ice Sports include Bobsleigh, Curling, Luge, Skating.

AIBA, International Boxing Association; BWF, Badminton World Federation; FEI, Fédération Equestre Internationale; FIBA, International Basketball Fédération; FIE, Fédération Internationale d'Escrime; FIFA, Fédération Internationale de Football Association; FIG, Fédération Internationale de Gymnastique; FIH, International Hockey Federation; FINA, Fédération Internationale de Natation; FIS, Fédération Internationale de Ski; FISA, Fédération Internationale des Sociétés d'Aviron (World Rowing); FIVB, Fédération Internationale de VolleyBall; IAAF, International Association of Athletics Federations; IBSF, International Bobsleigh \& Skeleton Federation; IBU, International Biathlon Union; ICF, International Canoe Federation; IFSC, International Federation of Sport Climbing; IGF, International Golf Federation; IHF, International Handball Federation; IIHF, International Ice Hockey Federation; IJF, International Judo Federation; ISA, International Surfing Association; ISU, International Skating Union; ITF, International Tennis Federation; ITTF, International Table Tennis Federation; ISMF, International Ski Mountaineering Federation; ISSF, International Shooting Sport Federation; ITU, International Triathlon Union; IWF, International Weightlifting Federation; UCI, Union Cycliste Internationale; UIPM, Union Internationale de Pentathlon Moderne; UWW, United World Werstling; WA, World Archery; WCF, World Curling Federatoin; WR, World Rugby; WBSC, World Baseball Softball Confederation; WKF, World Karate Federation; WS, World Sailing; WSk, World Skate; WTF, World Taekwondo Federation.

Year NF founded: when two dates are present, the first is the date for the foundation of a national association or multi-sport federation and the second the date on which it became a French Federation (date taken into account for the correlation analysis).

When considering GS and WS at the two dates or their change over time, no differences were observed between team and individual sports or between summer and winter sports $(\mathrm{p}>0.05)$. There was a significant correlation between GS and WS in $2015(\mathrm{r}=0.789 ; \mathrm{p}<0.01)$ and $2018(\mathrm{r}=0.741 ; \mathrm{p}<0.01)$. There was no correlation for GS and WS in 2015, 2018 or their change over time with the membership of each FOF $(r=-0.149-0.309 ; p>0.05)$. 


\begin{tabular}{|l|l|l|l|}
\hline Topics & $\mathbf{2 0 1 5}$ & $\mathbf{2 0 1 8}$ & \% of change \\
\hline \begin{tabular}{l} 
Medical rules \\
\hline $\begin{array}{l}\text { Pre-participation medical } \\
\text { examination }\end{array}$
\end{tabular} & 83.9 & 98.9 & 6.0 \\
\hline $\begin{array}{l}\text { Pre-participation medical } \\
\text { certificate }\end{array}$ & 93.5 & 83.3 & 1.0 \\
\hline $\begin{array}{l}\text { Recommendations for } \\
\text { preventing cardiovascular } \\
\text { disease }\end{array}$ & 61.3 & 75.0 & -10.9 \\
\hline $\begin{array}{l}\text { Recommendations for injury } \\
\text { prevention }\end{array}$ & 67.7 & 77.8 & 22.4 \\
\hline $\begin{array}{l}\text { Training and warm-up } \\
\text { exercises }\end{array}$ & 77.4 & 75.0 & 14.8 \\
\hline Sport for health programme & 93.5 & 97.2 & -3.1 \\
\hline $\begin{array}{l}\text { Child \& health programme } \\
\text { First aid }\end{array}$ & 67.7 & 77.8 & 3.9 \\
\hline Fight against doping & 35.5 & 47.2 & 14.8 \\
\hline Nutrition & 100.0 & 97.2 & 33.1 \\
\hline Promoting fair play & 61.3 & 50.0 & -2.8 \\
\hline Mean & 77.4 & 100.0 & -18.4 \\
\hline SD & 76.1 & 80.3 & 29.2 \\
\hline & 18.5 & 17.4 & 7.5 \\
\hline
\end{tabular}

Table 2: Percentage of information available according to the topics, with changes from 2015 to 2018. Availability of information corresponded to score at least 1 at the Google Score or Website Score.

\section{Discussion}

The main findings of the present study were that 1) FOFs diffuse health-related information through their websites, since in $201850 \%$ of them were including $75 \%$ of our topic list on their websites, and only $14 \%$ had less than $50 \%$ of the topics covered, 2) availability of health-related information varied between FOFs without any correlation to the size of the FOF (number of members), and 3) the accessibility of the information varied with the topics. To the best of our knowledge this is the first study, to analyse the availability and accessibility of information regarding athletes' health protection and promoting sport for health on NF, IOC, NOC, or IF websites. Such an analysis is of great interest given the mission of these governing sporting bodies [1-4].

\subsection{FOFs play the game and diffuse health-related information}

Our results show that NFs (in this case FOFs) are actively promoting sport and the health protection of athletes [5]. Although not all the 12 topics were available on all the FOF websites, the fact that $86 \%$ had at least 6 topics on their website, and 50\% had 75\% or more, suggests that FOFs are trying to diffuse healthrelated information. Most FOFs improved their score between 2015 and 2018, indicating their willingness to make this information more easily available.

As an extension of the studies published by Mountjoy and Junge [3] and Mountjoy et al. [4], these results report the information actually available from NFs, rather than just the topics they declare to be a priority 
for health. Declarations are easy but the practical information now available is encouraging as it proves that the governing sporting bodies are taking seriously their responsibility of informing the public [1-4,10]. It is obvious that the IOC, NOCs, IFs and NFs should provide only valid, and if possible evidence-based information, and the quality of their message is all-important if athletes and patients are to have confidence in what they read [15]. No qualitative analysis was carried out in this study (or in the work analysing the priorities of IFs [3,4]), but could be an interesting future extension to our work.

\subsection{Health-related information varied according to topics}

The most available and easy to find information concerned 'Anti-doping', 'Medical certificate', and 'Sport for Health', all fundamental topics to the FOFs. As the 'Fight against doping' is a top priority for IFs [3,4,16], we can assume that this is also true for NFs as without such a policy these NFs would not be approved by the IOC, nor be allowed to participate in the OGs. Doping has serious repercussions for the image of sport and the health of athletes; hardly surprising then that it is so prominent on websites.

A medical certificate is mandatory for any affiliate to a NF in France (https://www.legifrance.gouv.fr/eli/decret/2016/8/24/VJSV1621537D/jo/texte). FOFs make this information easy to find on their websites so that potential members will not be discouraged when unable to find the information they need.

Although everyone knows that physical activity is beneficial to health $[17,18]$ someone taking up a sport is an opportunity for an FOF to increase its membership. Giving prominence to 'sport for health' information is not only a public health issue, but also an economic one for the sporting federation.

\subsection{More information now available}

Our results show significant improvements in the availability of information from 2015 to 2018. The Internet is constantly evolving and growing exponentially so websites too must change to continue to attract people to their sites. Presumably this is also true for NFs as their websites are the showcase for their sport, both with athletes and the general public and a means to attract new members particularly through the diffusion of more health-related information and the general boost given to sport for Paris 2024.

\subsection{Methodological considerations}

Compared to previous studies asking IFs about their priorities and activities [3,4] our work shows no selfreporting bias. The scores obtained give an objective evaluation of the availability and accessibility of health-related information. The Website Score measured not only the availability on a site of an item but also how easy it was to access this information. These searches were all carried out by the same person, both in 2015 and 2018 over a period of two weeks in order to limit potential bias as websites were updated. Other sources of medical information than internet are available to the public [8]. People may also seek this information on more generic rather than NF websites. We did not judge the content of the information. We intentionally designed the study to target Olympic NFs, the results and their implications are thus limited to these specific NFs. The analysis between the individual vs. team sports, and summer vs. winter Olympic sports should be interpreted with caution due to the low number of FOFs in team and winter sports. Although we used two methods to find our information (via the Google search engine or directly from the FOF website), this many of course not reflect how everyone would try to access such 
information [19]. Finally, particularity of French sports (e.g. mandatory medical certificate) could bias information presented by FOFs in comparison to NFs from other countries.

\subsection{Practical implications and perspectives}

Our results could help FOFs improve their health-related communication. Some generic advice for improvements would include: i) improving how to find health/medical information on websites; ii) proposing a model for a medical certificate to download and print in .pdf format with a brief review of the legislation, the appropriate medical examination and specific contra-indications for the sport; iii) include the existing health-related programs proposed by the French government (e.g. ' 10 gold reflexes for health': http://www.sports.gouv.fr/10reflexesenor/index.html); and iv) other improvements could be made to improve the trust and credibility of the website [20]. Those topics ignored or under-developed on FOF websites should be targeted.

Further studies using similar methods should be conducted for IFs, NOCs, and even for other NFs. Looking at the information provided by IF websites in comparison to their declared priorities would also be relevant, as would evaluating the quality and readability of this information.

\section{Conclusion}

The FOFs are engaged in diffusing health-related information via their websites, although the availability and accessibility of this information varies according to FOFs and topics. These results should help FOFs to orientate their efforts to improve the availability and accessibility of information on athletes' health protection and sport promotion for health via their websites.

\section{Conflict of interest}

No potential conflict of interest declared

\section{Funding}

No funding

\section{Ethical statement}

Since the present study did not involve human subjects the Ethical Approval or subjects' informed consent was not necessary.

\section{Corresponding author $\square$}


Pascal Edouard, MD PhD

Department of Clinical and Exercise

Physiology, Sports medicine unity,

IRMIS, Campus Santé Innovations

University Hospital of Saint-Etienne

42055 Saint-Etienne cedex 2

France

Tel.: +33674574691

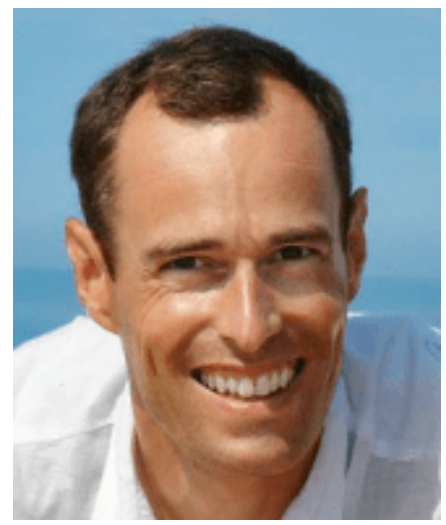

\section{References}

1. International Olympic Committee. Olympic Charter. force as from 2 August 2015

https//stillmed.olympic.org/Documents/olympic_charter_en.pdf;:1-110.doi:10.1080/01436597.2016.117 7455.

2. International Olympic Committee. Olympic Movement Medical Code. force as from 31 March 2016 https//stillmed.olympic.org/media/Document\%20Library/OlympicOrg/IOC/Who-WeAre/Commissions/Medical-and-Scientific-Commission/Olympic-Movement-MedicalCode-31-03-2016.pdf.2016;:1-11.https://stillmed.olympic.org/media/Document Library/OlympicOrg/IOC/Who-We-Are/Commissions/Medical-and-Scientific-Commission/OlympicMovement-Medical-Code-31-03-2016.pdf\#_ga=1.202686996.406591911.1477335095.

3. Mountjoy M, Junge A. The role of International Sport Federations in the protection of the athlete's health and promotion of sport for health of the general population. Br J Sports Med 2013;47:1023-7.doi:10.1136/bjsports-2013-092999.

4. Mountjoy M, Costa A, Budgett R, et al. Health promotion through sport: International sport federations' priorities, actions and opportunities. Br J Sports Med 2018;52:54-60.doi:10.1136/bjsports-2017- 097900.

5. Finch C. A new framework for research leading to sports injury prevention. J Sci Med Sport 2006;9:3-9.doi:10.1016/j.jsams.2006.02.009.

6. Renahy E, Chauvin P. Internet uses for health information seeking: A literature review. Rev Epidemiol Sante Publique 2006;54:263-75. doi:10.1016/S0398-7620(06)76721-9.

7. Demiris G. Consumer Health Informatics: Past, Present, and Future of a Rapidly Evolving Domain. Yearb Med Inform 2016;:S42-7. doi:10.15265/IYS-2016-s005.

8. Gerbing K, Thiel A. Handling of medical knowledge in sport: Athletes' medical opinions, information seeking behaviours and knowledge sources. Eur J Sport Sci 2016;16:141-8.doi:10.1080/17461391.2014.989278.

9. Hanstad DV, Ronsen O, Andersen SS, et al. Fit for the fight? Illnesses in the Norwegian team in the Vancouver Olympic Games. Br J Sports Med 2011;45:571-5.doi:10.1136/bjsm.2010.081364.

10. Engebretsen L, Steffen K. Protection of the elite athlete is the responsibility of all of us in sports medicine. Br J Sports Med 2015;49:1089-90.doi:10.1136/bjsports-2015-095221.

11. Cummins S, Clark C, Lewis D, et al. The effects of the London 2012 Olympics and related urban regeneration on physical and mental health: the ORiEL mixed-methods evaluation of a natural experiment. Public Heal Res 2018;6:1-248.doi:10.3310/phr06120.

12. Pigozzi F. Specialisation in sports medicine: The state of the Sport Medicine Specialty Training Core 
Curriculum in the European Union. Br J Sports Med 2009;43:1085-7.doi:10.1136/bjsm.2008.055350.

13. Giustini D. How Google is changing medicine. Br Med J 2005;

331:1487-8.doi:10.1136/bmj.331.7531.1487.

14. Henderson J. Google Scholar: A source for clinicians? Can Med Assoc J 2005;172:1549-50.

15. Riis A, Hjelmager DM, Vinther LD, et al. Preferences for web-based information material for low back pain: Qualitative interview study on people consulting a general practitioner. J Med Internet Res 2018;5:1-10. doi:10.2196/rehab.8841.

16. Mountjoy M, Miller S, Vallini M, et al. International Sports Federation's fight to protect the clean athlete: Are we doing enough in the fight against doping? Br J Sports Med 2017;51:1241-2.doi:10.1136/bjsports-2017-097870.

17. Lee I, Shiroma EJ, Lobelo F, et al. Effect of physical inactivity on major non-communicable diseases worldwide: an analysis of burden of disease and life expectancy. Lancet 2008;380:219-29.doi:10.1016/S0140-6736(12)61031-9.

18. Pedersen BK, Saltin B. Evidence for prescribing exercise as therapy in chronic disease. Scand J Med Sci Sport 2016;16:3-63.doi:10.1111/sms.12581.

19. Eysenbach G, Köhler C. BMJ Publishing Group How Do Consumers Search For And Appraise Health Information On The World Wide Web? Qualitative Study Using Focus Groups , Usability Tests, And InDepth Interviews Committee (JISC) in the UK. This content is also freely available. Br Med J 2002;324:573-7.

20. Sbaffi L, Rowley J. Trust and credibility in web-based health information: A review and agenda for future research. J Med Internet Res 2017; 19:e218.doi:10.2196/jmir.7579. 